Pediat. Res. 6: 481-486 (1972)

Follicle-stimulating

hormone

gonadotropins luteinizing hormone

puberty

releasing factor

\title{
Characterization of the Hormonal Responses to Luteinizing Hormone-Releasing Hormone (LH-RH) in Prepubertal and Adult Subjects
}

\author{
Abba J. Kastin ${ }^{[28]}$, Andrew V. Schally, Don S. Schalch, Stanley G. Korenman, \\ M. Gijnton Mrller, iII, Garlos Gual, and Enriove Perez-Pasten
}

Endocrinology Section of the Medical Service and Endocrine and Polypeptide Laboratories, Veterans Administration Hospital and Department of Medicine, Tulane University School of Medicine, New Orleans, Louisiana; Department of Medicine, University of Rochester School of Medicine and Dentistry, Rochester, New York; Department of Medicine, University of Iowa School of Medicine, Iowa City, Iowa; Department of Biometry, Medical University of South Carolina, Charleston, South Carolina, USA; and Instituto Nacional de la Nutricion and Hospital de Pediatria, Centro Medico Nacional, IMSS, Mexico City, Mexico

\section{Extract}

Luteinizing hormone-releasing hormone $(\mathrm{LH}-\mathrm{RH})$, purified from porcine hypothalamic tissue, was administered in an intravenous dose of $300 \mu \mathrm{g}$ to four prepubertal and four adult human subjects. The resulting increases in plasma levels of $\mathrm{LH}$ and FSH were statistically significant $(P<0.01)$ in the 16- and 32-min samples, but did not differ with the age or sex of the subject groups. The mean maximum increase in plasma $\mathrm{LH}$ values was $290 \%$ for men and $425 \%$ for women. Injection of $\mathrm{LH}-\mathrm{RH}$ resulted in a $500 \%$ mean maximum increase in LH levels in the plasma of boys and $850 \%$ in that of girls. The gonadotropin release induced by injection of LH-RH was sufficient to increase plasma levels of estradiol in some individuals. No significant elevation occurred in the levels in plasma of growth hormone, thyrotropin, or cortisol. It is concluded that LH-RH is a potent and specific hypothalamic releasing hormone for $\mathrm{LH}$ and FSH in prepubertal children as well as in normal adults.

\section{Speculation}

The increases in gonadotropin levels in plasma of all groups seem to reduce the possibility that a change in pituitary responsiveness to LH-RH occurs at puberty. However, similar studies involving larger numbers of individuals tested at varying doses might reveal differences in responses to LH-RH between age or sex groups.

\section{Introduction}

It is now well established that the hypothalamus produces substances which regulate the release of hormones from the adenohypophysis [19, 20, 22]. One of these hypothalamic substances, which controls the release of luteinizing hormone (LH), has been found in hypothalamic tissue from at least seven animal species, including man [17]. Injection of hypothalamic LH-releasing hormone (LH-RH) results in stimulation of the release of $\mathrm{LH}$ from the pituitary gland of a number of animals $[17,19,20,22]$.

Although LH-RH prepared from human hypothal- 
ami is effective in releasing $\mathrm{LH}$ in man [4], all other clinical studies with LH-RH have used a highly purified LH-RH preparation of porcine origin except one [13], in which a crude ovine hypothalamic extract was injected. Administration of porcine LH-RH clearly was shown to increase levels in serum of $\mathrm{LH}$ and follicle-stimulating hormone (FSH) in normal men and women [5], even when injected subcutaneously [6]. A linear $\log$ dose-response relation has been demonstrated with this material [7]. The increased release of gonadotropins occurred regardless of whether the initial levels of LH and FSH were elevated, as in postmenopausal women [6] and in men [8] pretreated with clomiphene, or whether LH was suppressed by estrogen or an oral contraceptive $[5,6]$. The presence of secondary amenorrhea in some wómen did not prevent the release of $\mathrm{LH}$ caused by LH-RH [6]; indeed, administration of LH-RH was associated with the induction of ovulation and subsequent pregnancy in one such subject [9]. LH-RH has also been suggested as a diagnostic test of pituitary function $[1,3]$.

The mechanisms resulting in initiation of puberty are unknown. Three hypotheses for the latency of reproductive activity in the prepubertal state are (1) lack of sensitivity of the gonads to gonadotropins, (2) lack of sensitivity of the pituitary to LH-RH, and (3) lack of synthesis or release of LH-RH, or both. That the "gonads are able to function in an adult fashion long before puberty" is well known [2]. The third hypothesis cannot be tested at the present time, but an increased sensitivity of the pituitary gland to the gonadotropin-releasing hormone, LH-RH, might occur at puberty. If this happened, children would be expected to be less responsive to the LH- and FSH-releasing effects of LH-RH than adults. This hypothesis was examined in the present study. In addition, the specificity of LH-RH was investigated by measurement of the effects of its administration upon levels in plasma of thyrotropin (TSH), growth hormone (GH), and cortisol as well as LH and FSH. Furthermore, it was determined whether the LH released by LH-RH was sufficient to elevate estradiol in the plasma.

\section{Materials and Methods}

Purified LH-RH was prepared by acetic acid extraction of porcine hypothalamic tissue followed by gel filtration on Sephadex, concentration by phenol, chromatography and rechromatography on carboxymethylcellulose, free-flow electrophoresis, and countercurrent distribution, as described previously [20, 21]. This preparation of LH-RH was approximately one-tenth as potent in rat assays as our most highly purified LH-RH preparation [18]. It contained approximately 0.1 pressor unit $/ \mathrm{mg}$ but was free of anterior pituitary and other hypothalamic releasing hormones.

A dose of $300 \mu \mathrm{g}$ porcine LH-RH was injected intravenously at time 0 and blood samples were collected 8 , $16,32,64,128$, and $480 \mathrm{~min}$ later. Plasma levels of LH [16], FSH [14], TSH [24], and GH [15] were determined by radioimmunoassay; plasma cortisol [12] and estradiol [10] levels were measured by radioligand assay. One nanogram of $\mathrm{LH}=10$ milli-international units (mIU) of Second International Reference Preparation human menopausal gonadotropin (2nd IRPHMG), $1 \mathrm{ng} F S H=4 \mathrm{mIU}$ 2nd IRP-HMG, and $1 \mathrm{ng}$ $\mathrm{TSH}=3.2 \mu \mathrm{U}$. These assays can detect $0.2 \mathrm{ng} / \mathrm{ml}$ of $\mathrm{LH}$ and FSH, $1 \mathrm{ng}$ of TSH, $1 \mathrm{ng}$ of GH, and $4 \mu \mathrm{g} / 100$ $\mathrm{ml}$ of cortisol. It was possible in occasional assays to detect less than $6 \mathrm{pg} / \mathrm{ml}$ of estradiol by extracting several milliliters of plasma. The LH-RH caused no side effects.

Two subjects were tested in each of four groups. The two boys were 10 and 11 years old, the two girls 8 and 10 years old, the two men 26 and 30 years old, and the two women 19 and 20 years old. None of the children had undergone puberty. Informed written consent was obtained from each adult and from an authorized representative of each child.

A least squares analysis of variance was performed on the six dependent variables: LH, FSH, TSH, GH, cortisol, and estradiol. The experimental design was that of a four-factor, partially nested experiment with repeated measures [23]. The four factors were age, sex, subjects within age-sex group, and time.

\section{Results}

\section{Luteinizing Hormone}

The mean response of levels of $\mathrm{LH}$ in plasma to administration of LH-RH for each group of subjects is illustrated in Figure 1. Although it appears that the prepubertal group might be more responsive than the adults, this was not statistically significant, perhaps because of the small number of subjects. The results of the statistical analyses are summarized in Table I where it is apparent that there was no difference in response to LH-RH by males and females, regardless of age, although there was considerable variability among subjects (Table II). The increased levels of LH in plasma with time were highly significant in the 16- 


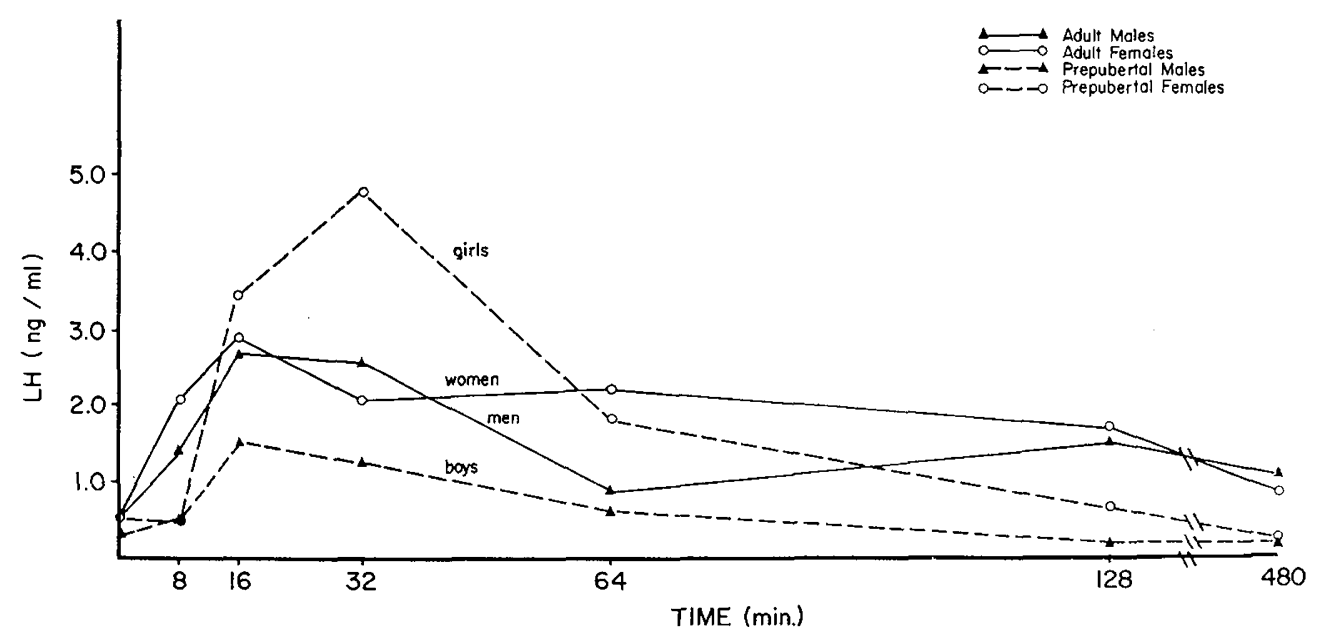

Fig. 1. Mean responses of levels of luteinizing hormone (LH) in plasma to administration of porcine luteinizing hormone-releasing hormone $\mathrm{n}$ four groups of subjects ( $\mathrm{ng} \mathrm{LH}=10 \mathrm{mIU}$ 2nd IRP-HMG).

and 32-min samples. The mean maximum increases were as follows: men, $290 \%$; women, $465 \%$; boys, $500 \%$; girls, $850 \%$.

\section{Follicle-Stimulating Hormone}

Figure 2 illustrates the mean responses of FSH to injection of LH-RH in each of the four age-sex groups. As with LH, the responses of FSH in the subjects were significantly different, and the maximum increases in FSH release were found 16 and 32 min after injection of LH-RH (Tables $I$ and $\mathrm{II}$ ). In contrast to the release of LH, the responses of FSH to LH-RH tended to be greater in the adults than in the prepubertal groups. The base line levels of FSH were higher in the children. It is not known whether a differential effect of the negative feedback action of the sex steroids is involved.

\section{Thyrotropin}

As summarized in Table $\mathrm{I}$, there was no significant effect of LH-RH upon the release of TSH. The subjects did have significant differences in their TSH levels, however, which were not related to the treatment.

\section{Growth Hormone}

Luteinizing hormone-releasing hormone caused no statistically significant release of growth hormone (Table I). The levels of GH in women were slightly, but not significantly higher $(P<0.10)$ than in the males.
Table I. Variance of responses to porcine $\mathrm{LH}-\mathrm{RH}^{1}$

\begin{tabular}{|c|c|c|c|c|c|c|}
\hline Variant & $\mathrm{LH}^{2}$ & $\mathrm{FSH}^{3}$ & $\mathrm{TSH}^{4}$ & $\mathrm{GH}^{5}$ & $\begin{array}{l}\text { Cor- } \\
\text { tisol }\end{array}$ & $\begin{array}{c}\text { Estra- } \\
\text { diol }\end{array}$ \\
\hline Adult vs child & - & - & - & $t^{6}$ & - & - \\
\hline Male $v s$ female & - & - & - & - & - & - \\
\hline Sex $\times$ age & - & - & - & - & - & - \\
\hline $\begin{array}{l}\text { Patients/(age } \times \\
\text { sex) }\end{array}$ & $+^{6}$ & $+^{6}$ & $+^{7}$ & - & - & $t^{6}$ \\
\hline Time & $t^{6}$ & +7 & - & - & - & +7 \\
\hline Time $X$ age & - & - & - & - & - & - \\
\hline Time $X$ sex & - & - & - & - & - & $t^{7}$ \\
\hline Time $X$ age $X$ sex & - & - & - & - & - & $t^{6}$ \\
\hline $0-8 \mathrm{~min}$ & - & - & 一 & - & - & - \\
\hline $0-16 \min$ & $+^{6}$ & $t^{6}$ & - & - & $?$ & - \\
\hline $0-32 \mathrm{~min}$ & $t^{6}$ & $+^{6}$ & 一 & - & - & $t^{6}$ \\
\hline $0-64 \mathrm{~min}$ & - & $t^{7}$ & - & - & - & - \\
\hline $0-128 \mathrm{~min}$ & - & - & - & - & - & - \\
\hline $0-8 \mathrm{hr}$ & - & - & - & - & - & - \\
\hline
\end{tabular}

$\sqrt{\text { LH-RH : luteinizing hormone-releasing hormone. }}$

${ }^{2} \mathrm{LH}$ : Iuteinizing hormone.

${ }^{3} \mathrm{FSH}$ : follicle-stimulating hormone.

${ }^{4} \mathrm{TSH}$ : thyrotropin.

${ }^{5} \mathrm{GH}$ : growth hormone.

${ }^{6} P<0.01$.

${ }^{7} P<0.05$.

\section{Cortisol}

Although the analysis (Table I) indicates that the 16-min sample was significantly different from time 0 , the lack of significant differences in the subjects and the overall time category make it likely that this is a spurious statistical finding. Thus, LH-RH probably had no significant effect upon the release of cortisol. 
Table II. Levels of $\mathrm{LH}$ and FSH in plasma after administration of porcine LH-RHI

\begin{tabular}{|c|c|c|c|c|c|c|c|c|c|c|c|c|c|c|}
\hline \multirow[b]{2}{*}{ Time, min } & \multicolumn{7}{|c|}{$\mathrm{LH}^{2}$} & \multicolumn{7}{|c|}{$\mathrm{FSH}^{3}$} \\
\hline & 0 & 8 & 16 & 32 & 64 & 128 & 480 & 0 & 8 & 16 & 32 & 64 & 128 & 480 \\
\hline \multicolumn{15}{|l|}{ Subjects } \\
\hline Boy & 0.2 & 0.2 & 2.1 & 1.6 & 0.8 & 0.2 & 0.2 & 1.3 & 2.3 & 1.8 & 1.5 & 2.6 & 0.2 & 2.0 \\
\hline Boy & 0.3 & 0.8 & 0.9 & 0.9 & 0.4 & 0.2 & 0.2 & 0.9 & 2.5 & 2.7 & 2.4 & 2.0 & 3.8 & 1.3 \\
\hline Girl & 0.2 & 0.2 & 0.3 & 2.0 & 0.9 & 0.2 & 0.2 & 0.2 & 0.2 & 0.5 & 1.5 & 0.7 & 0.6 & 0.5 \\
\hline Girl & 0.8 & 0.8 & 6.6 & 7.5 & 2.7 & 1.1 & 0.3 & 2.9 & 2.3 & 4.7 & 5.5 & 2.5 & 2.9 & 2.9 \\
\hline Man & 0.7 & & 3.6 & 3.0 & 1.0 & 1.8 & 1.0 & 0.4 & & 2.3 & 3.4 & 1.3 & 1.3 & 1.3 \\
\hline Man & 0.6 & 1.4 & 1.7 & 2.1 & 0.8 & 1.2 & 1.2 & 0.6 & 1.0 & 3.2 & 2.0 & 2.7 & 1.1 & 1.0 \\
\hline Woman & 0.7 & 3.9 & 5.6 & 2.9 & 3.7 & 1.5 & 1.2 & 0.3 & 6.3 & 7.0 & 8.3 & 4.0 & 3.2 & 3.0 \\
\hline Woman & 0.4 & 0.2 & 0.2 & 1.2 & 0.7 & 0.9 & 0.5 & 0.2 & 1.0 & 0.2 & 0.8 & 1.0 & 0.8 & 0.2 \\
\hline
\end{tabular}

${ }_{1}$ LH-RH : luteinizing hormone-releasing hormone.

${ }^{2} \mathrm{LH}$ : luteinizing hormone, in $\mathrm{ng} / \mathrm{ml}$.

${ }^{3} \mathrm{FSH}$ : follicle-stimulating hormone, in $\mathrm{ng} / \mathrm{ml}$.



Fig. 2. Mean responses of levels of follicle-stimulating hormone (FSH) in plasma to administration of porcine luteinizing hormone-releasing hormone in four groups of subjects ( $1 \mathrm{ng} F S H=4 \mathrm{mIU}$ 2nd IRP-HMG).

Table III. Levels of estradiol (picograms per milliliter) in plasma after administration of porcine LH-RH ${ }^{1}$

\begin{tabular}{lrrrr}
\hline \multirow{2}{*}{ Subject } & \multicolumn{4}{c}{ Time, min } \\
\cline { 2 - 5 } & \multicolumn{1}{c}{0} & \multicolumn{1}{c}{32} & 128 & 480 \\
\hline Boy & 0 & 5 & 15 & 19 \\
Boy & 8 & 17 & 23 & 6 \\
Girl & 0 & 8 & 9 & 0 \\
Girl & 104 & 118 & 126 & 106 \\
Man & 20 & 82 & 39 & 19 \\
Man & 42 & 88 & 20 & 23 \\
Woman & 99 & 112 & 125 & 162 \\
Woman & 37 & 34 & 40 & 50 \\
\hline
\end{tabular}

LH-RH : luteinizing hormone-releasing hormone.

\section{Estradiol}

Estradiol was determined in samples of plasma obtained at $0,32,128$, and $480 \mathrm{~min}$. The time $\times$ sex inter- action was statistically significant, indicating a difference between males and females over time after injection with LH-RH (Table I). In this study, only the males responded to LH-RH with an increased release of estradiol, an increase which was highly significant in the 32-min sample. This might represent increased conversion from testosterone. The data are presented in Table III.

\section{Discussion}

Previous studies have shown that adult men and women respond to the administration of highly purified porcine LH-RH with a significant release of $\mathrm{LH}$ [5-7]. No significant difference in response between men and women was found [5]. The present investigation confirmed these findings, although the total num- 
ber of cases was small. The significant increase in levels of $\mathrm{LH}$ in plasma after injection of $\mathrm{LH}-\mathrm{RH}$ was of the same magnitude in men and women (Fig. 1, Table I).

In every clinical study in which porcine LH-RH has been administered, a significant increase in levels of FSH in plasma accompanied the rise in LH values. Since a homogeneous natural [18] or synthetic [11] preparation of LH-RH releases FSH in the rat, it now appears that the FSH-releasing effect of LH-RH is intrinsic to LH-RH rather than due to contamination with an FSH-releasing hormone. Significant elevation of levels of FSH in plasma was also observed in the present study (Fig. 2, Table I).

The response of the prepubertal pituitary to $\mathrm{LH}$ $\mathrm{RH}$, as measured by release of $\mathrm{LH}$ and $\mathrm{FSH}$, was at least as great as that of the adult pituitary. Thus it is unlikely that puberty represents a state of increasing responsiveness to the hypothalamic gonadotropin-releasing hormone. Inasmuch as a change in gonadal sensitivity has already been eliminated as an explanation [2], the hypothalamus or higher central nervous system is probably the site for the initiation of puberty.

Root et al. [13] injected "crude ovine hypothalamic extract" into "two human infants with lethal chromosomal anomalies and multiple congenital anomalies and into one child with severe cerebral dysfunction." An increase in plasma $\mathrm{LH}$ was observed in all subjects after they received a dose several hundred times greater than that employed in the present study.

Experiments in animals have shown that LH-RH does not release other pituitary hormones [17, 19, 20, 22]. No statistically significant increase in TSH, GH, or cortisol release was found in our human subjects after injection of LH-RH (Table I).

Additional evidence for the relative specificity of LH-RH in the human being is provided by the lack of a significant effect upon $\mathrm{LH}$ and FSH release of the administration of 0.1 to 1.0 unit of lysine or arginine vasopressin [4-6]. These doses of vasopressin were approximately equivalent to or exceeded the amounts which the subjects received in the porcine LH-RH preparations.

The increased levels of gonadotropin induced by administration of LH-RH were sufficient to result in increased estradiol levels in the males, but not in the females. The hypothesis that the LH released by administration of LH-RH can stimulate a target gland received additional support from a case in which ovulation was apparently induced by LH-RH [9]. In this instance, pregnancy provided conclusive proof of ovulation.

\section{Summary}

Highly purified porcine LH-RH was injected intravenously into two boys, two girls, two men, and two women. A statistically significant increase in levels of $\mathrm{LH}$ and FSH in plasma resulted in all groups regardless of age or sex. Levels of GH, TSH, and cortisol in plasma were not significantly changed by the LH-RH. The gonadotropin released by LH-RH was apparently sufficient to increase levels of estradiol in plasma of the males. Thus, investigations with LH-RH might help to elucidate the physiologic mechanisms involved in puberty and in the reproductive cycle.

\section{References and Notes}

1. Gual, C., Kastin, A. J., Midgley, A. R., And Flores, F.: Administration of LH-releasing hormone (LH-RH) as a clinical test of pituitary function. Program of the 53rd Endocrine Society Meeting, 1971, p. A-128.

2. HARris, G. W.: Neural Control of the Pituitary Gland, p. 93. (Edward Arnold, London, 1955).

3. Kastin, A. J., Schally, A. V., Gonzalez-Barcena, D., Schalch, D. S., AND LEE, L.: Different responses to two hypothalamic hormones in acromegalics. Arch Intern. Med. (in press).

4. Kastin, A. J., Schally, A. V., Gual, C., Midgley, A. R., Arimura, A., Miller, M. C., and CabezA, A.: Administration of LH-releasing hormone of human origin to man. J. Clin. Endocrinol. Metab., 32: 287 (1971).

5. Kastin, A. J., Schally, A. V., Gual, G., Midgley, A. R., Bowers, C. Y., and Diaz-Infante, A.: Stimulation of LH release in men and women by LH-releasing hormone purified from porcine hypothalami. J. Clin. Endocrinol. Metab., 29: 1046 (1969).

6. Kastin, A. J., Schally, A. V., Gual, C., Midgley, A. R., Bowers, C. Y., AND GoMez-PEREZ, F.: Administration of LHreleasing hormone to selected subjects. Amer. J. Obstet. Gynecol., 108: 177 (1970).

7. Kastin, A. J., Schally, A. V., Gual, G., Midgley, A. R. Miller, M. C., AND CABezA, A.: Dose-response relationship of LH to LH-releasing hormone in man. J. Clin. Invest., 50: 1551 (1971).

8. Kastin, A. J., Schally, A. V., Gual, C., Midgley, A. R., Miller, M. C., AND Flores, F.: Increased release of LH after administration of LH-RH to men pretreated with clomiphene. J. Clin. Endocrinol. Metab., 31: 689 (1970).

9. Kastin, A. J., Zarate, A., Midgley, A. R., Canales, E. S., AND SCHally, A. V.: Ovulation confirmed by pregnancy after infusion of porcine LH-RH. J. Clin. Endocrinol. Metab., 33: 980 (1971).

10. Korenman, S. G., Tulchinsky, D., and Eaton, L. W., JR.: Radioligand procedures for estrogen assay in normal and pregnancy plasma. Acta Endocrinol. Suppl., 147: 291 (1970).

11. Matsuo, H., Baba, Y., Nair, R. M. G., Arimura, A., aNd Schally, A. V.: Structure of the porcine LH- and FSH-releasing hormone. I. The proposed amino acid sequence. Biochem. Biophys. Res. Commun., 43: 1334 (1971). 
12. Murphy, B. E. P.: Some studies of the protein-binding of steroids and their applications to the routine micro and ultra micro measurement of various steroids in body fluids by competitive protein binding radioassay. J. Clin. Endocrinol. Metab., 27: 973 (1967).

13. Root, A. W., Smith, G. P., Dhariwal, A. P. S., and McCann, S. M.: Luteinizing hormone releasing activity of crude ovine hypothalamic extract in man. Nature, 221: 570 (1969).

14. SCHALCH, D. S.: Gonadotropin secretion in the human. In: H. C. Mack and A. J. Sherman: Neuroendocrinology of Human Reproduction, p. 127. (Charles C Thomas, Springfield, Ill., 1971).

15. Schalch, D. S., and Parker, M. L.: A sensitive double antibody immunoassay for human growth hormone in plasma. Nature, 203: 1141 (1964).

16. Schalch, D. S., Parlow, A. F., Boon, R. G., and Reichlin, S.: Measurement of human luteinizing hormone in plasma by radioimmunoassay. J. Clin. Invest., 47: 665 (1968).

17. Schally, A. V., AND Kastin, A. J.: The role of sex steroids, hypothalamic LH-releasing hormone and FSH-releasing hormone in the regulation of gonadotropin secretion from the anterior pituitary gland. In: M. H. Briggs: Advances in Steroid Biochemistry and Pharmacology, Vol. 2, p. 41. (Academic Press, London, 1970).

18. Schally, A. V., Arimura, A., Baba, Y., Nair, R. M. G., Matsuo, H., Redding, T. W., Debeljuk, L., And White, W. F.: Isolation and properties of the FSH and LH-releasing hormone. Biochem. Biophys. Res. Commun., 43: 393 (1971).

19. Schally, A. V., Arimura, A., Bowers, C. Y., Kastin, A. J., Sawano, S., ANd Redding, T. W.: Hypothalamic neurohormones regulating anterior pituitary function. In: E. B. Ast- wood: Recent Progress in Hormone Research, Vol. 24, p. 497. (Academic Press, New York, 1968).

20. Schtally, A. V., Arimura, A., Kastin, A. J., Reeves, J., Bowers, C. Y., BABA, Y., AND WhITE, W. F.: Hypothalamic LH-releasing hormone: chemistry, physiology, and effect in humans. In: H. Gibian and E. J. Plotz: Mammalian Reproduction, p. 45. (Springer-Verlag, Berlin, 1970).

21. Schally, A. V., Bowers, C. Y., White, W. F., and Cohen, A. I.: Purification and in vivo and in vitro studies with porcine luteinizing hormone-releasing factor (LRF). Endocrinology, 81: 77 (1967).

22. Schally, A. V., Kastin, A. J., Locke, W., and Bowers, C. Y.: Hypothalamic releasing and inhibiting factors. In: C. $\mathrm{H}$. Gray and A. L. Bacharach: Hormones in Blood, Ed. 2, Vol. 1, p. 491. (Academic Press, London, 1967).

23. Steel, R. G. D., ANd ToRrie, J. H.: Principles and Procedures of Statistics, p. 194. (McGraw-Hill, New York, 1960).

24. UTIGER, R. D.: Radioimmunoassay of human plasma thyrotropin. J. Clin. Invest., 44: 1277 (1965).

25. The authors appreciate the help of Drs. A. Segaloff, S. Frenk, and E. B. Ferguson, Jx., and of the Central Office, Veterans Administration, Washington, D.C.

26. Presented in part at the 63rd Annual Meeting of the American Society for Clinical Investigation, 1971.

27. Supported by National Institutes of Health Grant no. AM08943 and by grants from the Veterans Administration and The Ford Foundation.

28. Requests for reprints should be addressed to: ABBA J. KASTIN, M.D., Veterans Administration Hospital, 1601 Perdida Street, New Orleans, La. 70146 (USA).

29. Accepted for publication November 12, 1971. 